\title{
RESIDUAL METHOD USED FOR COMMERCIAL REAL ESTATE VALUATION AND ITS SENSITIVITY
}

\author{
Josef Kupec ${ }^{1}$, Petr Dlask ${ }^{2}$ \\ ${ }^{1}$ Czech Technical University in Prague, Faculty of Civil Engineering, Thákurova 7, 16629 Praha 6 - \\ Dejvice, Czech Republic, kupecjos@fsv.cvut.cz \\ ${ }^{1}$ Czech Technical University in Prague, Faculty of Civil Engineering, Thákurova 7, 16629 Praha 6 - \\ Dejvice, Czech Republic,
}

\begin{abstract}
In real estate valuation it is essential to understand the modelling of the economic potential of the property. The residual value is in many cases the only possible way how to determinate market value of the undeveloped land or property under construction which is important for investors, banks or auditors. The methodology of calculation for residual method is described in several valuation standard. These standards are usually very general so they can be applied in different markets. The residual method of valuation is very sensitive to changes in key inputs. Small changes in variables such as sales volumes or build costs will have a disproportionate effect on residual value. The article is focused on the sensitivity of the residual method to changes in key inputs. Sensitivity analysis is tested on a model suitable especially for commercial real estate valuation and reflect current market conditions.
\end{abstract}

\section{Keywords}

Residual method, Real estate valuation, Development property, Sensitivity analysis, Commercial real estate, land valuation.

\section{JEL Classification}

R33 Nonagricultural and Nonresidential Real Estate Markets

DOI: https://doi.org/10.14311/bit.2020.02.02

Editorial information: journal Business \& IT, ISSN 2570-7434, CreativeCommons license (c) (1) published by CTU in Prague, 2020, http://bit.fsv.cvut.cz/ 


\section{Development property valuation}

According to the Internal valuation standards (IVS) there are two main approaches in relation to the valuation of the development property. [1] These are market approach and residual method. Obtaining comparable evidence of development land values is very difficult. Each site will differ widely in location, possible use determined in zooning plan, size, permissible density of development, restrictions, technical infrastructure and so on, making adjustments to a standard value per comparable unit almost impossible. The residual method is used to value development sites and existing properties that have potential to be redeveloped [2] and in many cases the only possible way how to determinate market value of the undeveloped land or property under construction.

The residual method is so called because it indicates the residual amount after deducting all known or anticipated costs required to complete the development from the anticipated value of the project when completed after consideration of the risk associated with completion of the project. Changes in key inputs may influence the residual value of a piece of land to an extent that competition may increase the value of the land for reasons that have little to do with its current use, and it is the valuation of these potential development rights [2].

\section{Model of residual valuation}

The residual method is a hybrid of basic valuation approaches. For commercial properties the combination of income and cost approach is used. For the correct determination of the residual value is necessary to consider a significant amount of valuation assumptions. The residual method is based on a simple economic concept - that the value of the land is calculated as a surplus remaining after all estimated development costs have been deducted from the estimated value of the completed development [3].

This is based on the completed "Gross Development Value" and the deduction of development costs and the developer's return to arrive at the residual value of the development property [1].

The residual method is based on the following equation:

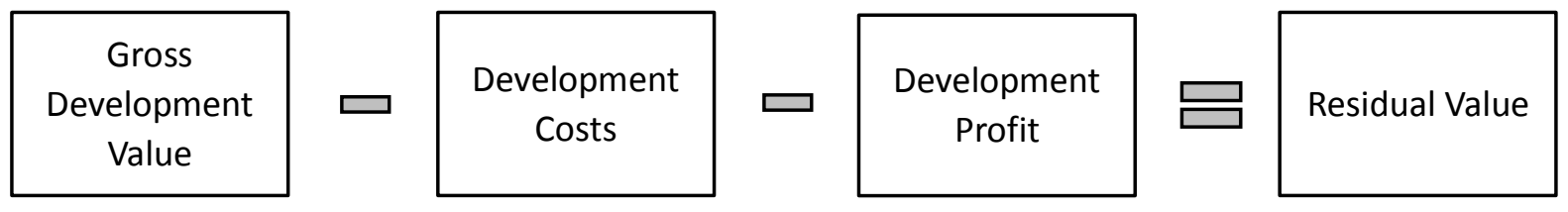

Figure 1: Basic calculation of the residual value (source: author)

\section{Gross Development Value}

At the beginning is necessary to determinate the Gross Development Value (GDV). Based on the fact that the property will be in the state of the best and highest use we can use the basic valuation approaches. Used valuation approach to determinate the GDV depends on the type of property. In the case of most commercial properties, the GDV will be calculated using the investment method of valuation.

This will require an estimation of the unit rent of the future property and the likely investment yield [5]. In practice the GDV is calculated as annual Estimated Rental Value p.a., after non recoverable costs deduction, divided by Equivalent Yield. Both key inputs reflect current market conditions and are usually determined based on a market comparison. The non recoverable costs include cots that are not normally charged to the tenants (etc. property tax, insurance, incidental costs). 
The RICS Code of measuring practice defines Net Internal Area as the usable area with a building measured to the internal face of the perimeter walls at each floor level [6]. NIA express property areas which generate revenues. Due to this fact they are used for the needs of Property Managers, Marketing, Real Estate Agents and Appraisers.

The calculation of the Gross Development Value is expressed by the formula

$$
G D V=(E R V \times N I A-\text { Non recoverable costs }) / E Y
$$

Where:

$$
\begin{aligned}
& \text { GDV } \quad \text { - Gross Development Value } \\
& \text { ERV } \quad \text { - Estimated Rental Value p.a. } \\
& \text { NIA } \quad \text { - Net Internal Area } \\
& \text { EY } \quad \text { - Equivalent Yield }
\end{aligned}
$$

\section{Development Costs}

Development costs always depend on the type of developer's intention and are unique for each project. The following basic elements require consideration in any application of the method to estimate the market value of the development property. Development costs consist of Construction costs, Soft costs and Financial costs.

\section{Construction cost (CC)}

The costs of all works required to complete the project to the defined highest and best use. The construction costs depend on the type and the phase of the construction project and include the construction cost (new object, reconstruction, utilities, landscaping, etc.), costs for ecological, demolition, disposal of ecological loads, off-site enabling work. The best possibility how to determinate the construction costs is a valid construction contract. If the contract is not available, the price indicators can be used to determine construction costs. For example, reference may be made to the Price indicators of the Czech construction standards [7]. Construction costs of commercial properties are divided to into Hard Costs and Fit outs. To include areas that cannot be rented the GEA/NIA Ratio is used. Gross External Area (GEA) is the area of a building measured externally at each floor level. To cover the risk connected with the additional cost is necessary to calculate the contingency fee.

The calculation of the Construction Costs is expressed by the formula

$$
C C=(G E A / N I A \text { Ratio } \times(N I A \times(\text { Hard Costs }+ \text { Fit outs costs }) \times \text { Contingency }
$$

Where:

CC - Construction Costs

GEA/NIA Ratio - Gross External Areal divided by Net Internal Area

NIA $\quad-$ Net Internal Area 


\section{Soft costs (SC)}

- Professional fees - These represent the cost of project studies, stages of the project documentation and the costs obtaining statutory premises and approvals. The level of professional fees depends on the difficulty of the project and are usually calculated as $5-10 \%$ of construction costs but may be a fixed sum.

- Project Management - These include the professional a project management costs that would be reasonably incurred by participants at various stages through to completion of the project. The level of Project Management fee depends on the difficulty of the project and are usually calculated as $5-10 \%$ of construction costs.

- Marketing - The cost of marketing may be entered as an estimated figure. Proper marketing is a part of the Market Value definition. It is normally to be appropriate to allow for the costs associated with appropriate marketing and would cover items such as advertising, opening ceremony, brochure design and production. Marketing is usually calculated as $2-4 \%$ of construction costs.

- Letting fee - Letting fees include the costs of legal services associated with the lease and services of real estate agents who provide for the lease of the future property. Letting fee is usually calculated as $10-20 \%$ of estimated rental value.

- Disposal fees - Disposal fees include the costs of legal services associated with the sale and services of real estate agents who provide for the sale of the future property. Disposal fee is usually calculated as $1-3 \%$ of gross development value.

The calculation of the Soft Costs is expressed by the formula

$S C=($ Professional Fees + Project Management + Marketing + Leting Fee + Disposal Fee

\section{Financial Costs}

These represent the cost of finance for the project through to the completion of the project, including any period required after physical completion to either sell the property. The traditional assumption is that the development and site purchase are financed using $100 \%$ borrowed money [2]. The amount of the financial costs depends on three key inputs - Interest rate, duration and amount borrowed. The Interest rate is usually constant through the whole project. The duration is usually divided into three separate periods in which the amount of the loan is changed. The figure 2 shows the calculation of Financial costs. 


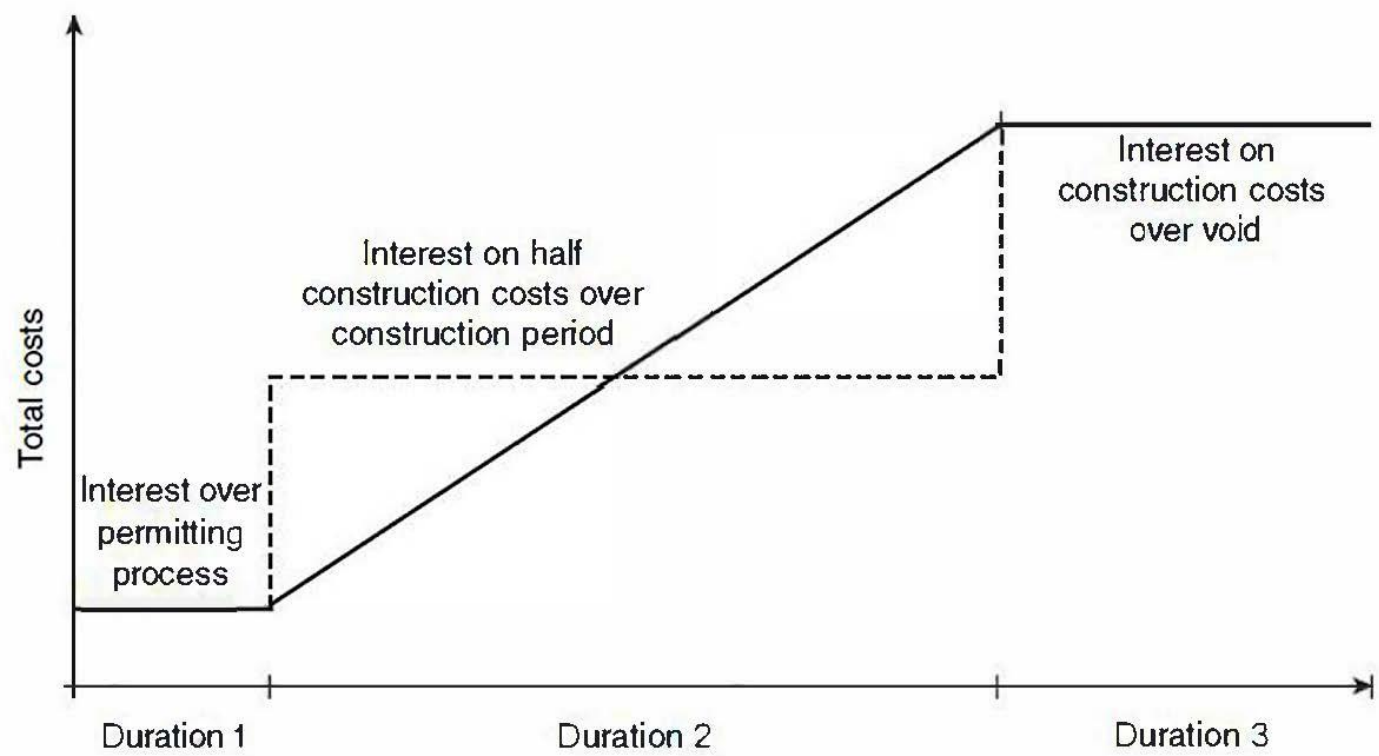

Figure 2: How interest is calculated (source: Wyatt)

The Duration 1 represents the period from the purchase of land to the obtaining a construction permit, the Duration 2 represents the period of the construction and the Duration 3 represents the process of occupation. The amount borrowed during permitting process and void period is constant and easy to calculate. The interest over construction period could be calculated as the annual interest on half of the costs over the construction period [3].

Total Financial costs are calculated as the sum of all periods.

$$
\begin{gathered}
I O P P+I O C P+I O V= \\
\left(A C \times I R \times D_{1}\right)+\left(A C+\frac{1}{2} C C+\frac{1}{2} S C\right) \times I R \times D_{2}+(A C+C C+S C) \times I R \times D_{3}
\end{gathered}
$$

Where:

$\begin{array}{ll}\text { IOPP } & \text { - Interest over permitting process } \\ \text { IOCP } & \text { - Interest over construction period } \\ \text { IOV } & \text { - Interest over void } \\ \text { AC } & \text { - Acquisition costs } \\ \text { CC } & \text { - Construction Costs } \\ \text { SC } & \text { - Soft Costs } \\ \text { IR } & \text { - Interest rate } \\ D_{1} & \text { - Duration } 1 \\ D_{2} & - \text { Duration } 2 \\ D_{3} & - \text { Duration } 3\end{array}$




\section{Development Profit}

The level of development profit depends on the type of property and is related to the amount of risk associated with achieving the expected return or capital value after the physical completion of the project. Development profit is the reward for initiating and finishing the development and is dependent upon the length and type of development, the size, the degree of competition for the site and whether it is pre-let or sold before construction is complete [4]. The level of developer profits is among the know-how of developers operating in the real estate market. Appraisers usually use for their valuation the level of the developer's profit based on the information provided by the developer and have only limited ability to assess its adequacy. Development profit is normally related either to the costs of the development or the completed development value; typically this might be $20-25 \%$ on Total cost, or 15-20\% on Gross Development Value [5]. Acquisition costs are equal to the residual value and represents the maximum amount that should be paid for the site.

The calculation of the Development Profit is expressed by the formula

$$
D P=(A C+C C+S C+F C) \times \%
$$

Where:

$$
\begin{array}{ll}
\text { DP } & \text { - Development Profit } \\
\text { AC } & \text { - Acquisition costs } \\
\text { CC } & \text { - Construction Costs } \\
\text { SC } & \text { - Soft Costs } \\
\text { FC } & \text { - Financial Costs }
\end{array}
$$

\section{Sensitivity analysis}

The use of the residual method varies according to the stage of the development process. The above described valuation model is very generalized in its assumptions and the technique is particularly suitable for property under construction and land valuation. The residual method of valuation is very sensitive to changes in key inputs. Small changes in variables such as sales volumes or build costs will have a disproportionate effect on residual value.

\section{Base model}

For the purpose of sensitivity analysis, we have taken a development site transaction realized in the first half of 2019 where transaction price is known. The transaction price was based on residual valuation calculation prepared by RICS certified valuer. The site is located in wilder center of Prague and allows the construction of an office building. Since the transaction information is confidential the estimated lettable area and other key inputs was slightly changed. Individual valuation assumptions were adapted to the residual model described above. The base residual valuation calculation is described in the Table 1. 
Table 1: Base Residual Value calculation (source: author)

\begin{tabular}{|c|c|c|c|}
\hline \multicolumn{4}{|c|}{ Gross Development Value } \\
\hline Estimated Rental Value per unit & & & $16,0 €$ \\
\hline Net Internal Area & & & 10000 \\
\hline Estimated Rental Value & & & $1920000 €$ \\
\hline Non Recoverable costs & & & $2 \%$ \\
\hline Net income p.a. & & & $1881600 €$ \\
\hline Equivalent Yield & & & $6,00 \%$ \\
\hline Gross Development Value & & & $31360000 €$ \\
\hline \multicolumn{4}{|c|}{ Development costs } \\
\hline \multicolumn{4}{|c|}{ Construction costs (CC) } \\
\hline GEA/NIA ratio & 1,1 & & \\
\hline Hard costs & $950 €$ & GEA & $10450000 €$ \\
\hline Fit-out & $200 €$ & GEA & $2200000 €$ \\
\hline Contingency & $5 \%$ & Hard costs + Fit-out & $632500 €$ \\
\hline \multicolumn{3}{|l|}{ Construction costs } & $13282500 €$ \\
\hline \multicolumn{4}{|c|}{ Soft Costs (SC) } \\
\hline & & Base & \\
\hline Professional fees & $7,0 \%$ & Construction costs & $929775 €$ \\
\hline Project management & $7,5 \%$ & Construction costs & $996188 €$ \\
\hline Marketing & $2,0 \%$ & Construction costs & $265650 €$ \\
\hline Letting fee & $15 \%$ & Estimated Rental Value per unit (ERV) & $288000 €$ \\
\hline Disposal fees & $2,5 \%$ & Gross Development Value (GDV) & $784000 €$ \\
\hline \multicolumn{3}{|l|}{ Soft Costs } & $3263613 €$ \\
\hline \multicolumn{4}{|c|}{ Financial costs } \\
\hline Acquisition costs & $7609376 €$ & & \\
\hline \multirow[t]{2}{*}{ Base interest rate } & $3,5 \%$ & & \\
\hline & Duration & Base & \\
\hline Land Acquisition & 24 & Acquisition costs (residual Value) & $532656 €$ \\
\hline Construction & 18 & Acquisition costs $+0,5 *(\mathrm{CC}+\mathrm{SC})$ & $833828 €$ \\
\hline Initial void & 3 & Acquisition costs $+\mathrm{CC}+\mathrm{SC}$ & $211361 €$ \\
\hline \multicolumn{3}{|l|}{ Financial costs } & $1577845 €$ \\
\hline \multicolumn{4}{|c|}{ Development profit } \\
\hline Rent frees & $25 \%$ & ERV & $480000 €$ \\
\hline Development profit & $20 \%$ & Total Costs & $5146667 €$ \\
\hline \multicolumn{3}{|l|}{ Base Residual Value } & $7609376 €$ \\
\hline
\end{tabular}

Considering the base valuation assumption, the Base Residual Value of the site was set to $7609376 €$. Changes in key inputs may have a positive or negative impact on value. The negative effect is more important from the point of view of banks, auditors or developers because its implications are more serious. An overvalued real estate carries a number of risks. For this reason, the impact of negative effects on the residual value is examined. In the compiled basic valuation model, sensitivity to individual inputs was examined subsequently was compared with the Base Residual Value. The author's team is aware of the fact that individual changes in inputs are not entirely comparable. However, they express the possible negative effects that may occur. The calculated differences are shown in the Table 2. 
Table 2: Sensitivity of key inputs (source: author)

\begin{tabular}{|c|c|c|c|c|}
\hline \multicolumn{5}{|c|}{ Sensitivity analysis } \\
\hline Key input & $\begin{array}{l}\text { Base } \\
\text { model }\end{array}$ & $\begin{array}{c}\text { Possible } \\
\text { negative effect }\end{array}$ & $\begin{array}{l}\text { Difference in } \\
\text { residual value }\end{array}$ & Description \\
\hline Estimated Rental Value & $16,0 €$ & $(-1,5 €)$ & $-26,8 \%$ & $\begin{array}{l}\text { Decrease of ERV due to market } \\
\text { condition }\end{array}$ \\
\hline Net Internal Area & 10000 & (- $1000 \mathrm{sqm})$ & $-10,0 \%$ & Decrease of NIA \\
\hline Non Recoverable costs & $2,0 \%$ & $(+2 \%)$ & $-6,0 \%$ & Increase of Non Recoverable costs \\
\hline Equivalent Yield & $6,0 \%$ & $(+0,5 \%)$ & $-22,6 \%$ & $\begin{array}{l}\text { Increase of EY due to market } \\
\text { condition }\end{array}$ \\
\hline GLA/NIA ratio & 1,10 & $(+0,05)$ & $-8,5 \%$ & GLA/NIA ratio extension \\
\hline Hard Costs & $950 €$ & $(+100 €)$ & $-16,2 \%$ & Overpriced Hard Costs \\
\hline Fit-outs & $200 €$ & $(+50 €)$ & $-8,1 \%$ & Overpriced Fit-outs \\
\hline Contingency & $5,0 \%$ & $(+5 \%)$ & $-8,9 \%$ & Contingency extension \\
\hline Professional fees & $7,0 \%$ & $(+2 \%)$ & $-3,2 \%$ & Overpriced professional fees \\
\hline Project management & $7,5 \%$ & $(+2 \%)$ & $-3,2 \%$ & Overpriced project management \\
\hline Marketing & $2,0 \%$ & $(+2 \%)$ & $-3,2 \%$ & Overpriced marketing \\
\hline Letting fee & $15,0 \%$ & $(+10 \%)$ & $-2,3 \%$ & Complication in letting \\
\hline Disposal fees & $2,5 \%$ & $(+1,0 \%)$ & $-5,7 \%$ & Complication in sale \\
\hline Base interest rate & $3,5 \%$ & $(+2,0 \%)$ & $-9,8 \%$ & Increase of interest rate \\
\hline $\begin{array}{l}\text { Duration } 1 \text { - permitting } \\
\text { process }\end{array}$ & 24 & +1 Year & $-3,0 \%$ & Delay in permitting process \\
\hline $\begin{array}{l}\text { Duration } 2 \text { - } \\
\text { construction process }\end{array}$ & 18 & +1 Year & $-6,3 \%$ & Delay in construction \\
\hline $\begin{array}{l}\text { Duration } 3 \text { - occupancy } \\
\text { process }\end{array}$ & 3 & +1 Year & $-9,5 \%$ & Delay in occupancy process \\
\hline Development profit & $20,0 \%$ & $(+5 \%)$ & $-12,0 \%$ & Higher level of development profit \\
\hline
\end{tabular}

The above analysis shows that the most critical key inputs are Estimated Rental Value and Equivalent Yield which are key inputs for Gross Development Value calculation.

The best way to verify the level of Equivalent Yield is the comparison with realized transaction of comparable properties. Market research processed by consultancy company Cushman \& Wakefield shows that between second quarters of 2018 and 2019 the prime office yield was compressed by 30 base points from $4,5 \%$ to $4,2 \%[8,9]$. This market improvement results in a significant increase in the value of sites suitable for commercial development. The figure 3 shows the sensitivity of the residual value on the level of the Equivalent Yield. 


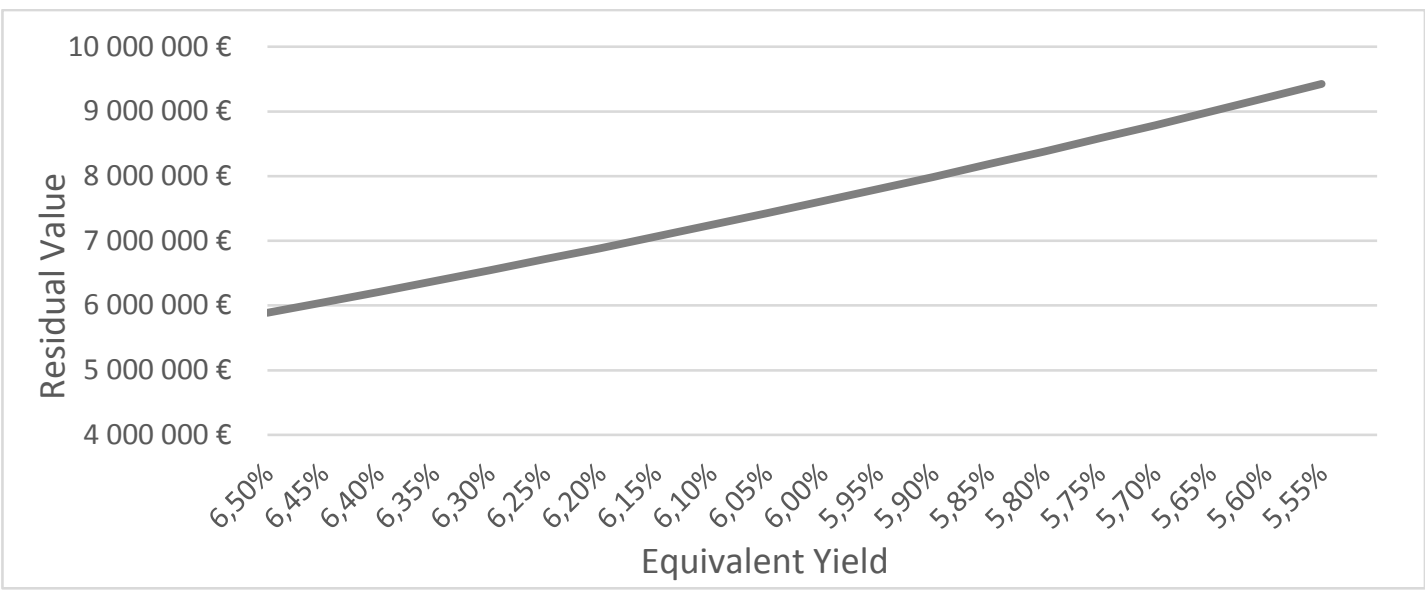

Figure 3: Sensitivity of residual value on EY (source: Autor)

If possible, the Estimated Rental Value should be supported by lease contracts or real estate advertising of comparable premises in the locality. In order to proper residual value calculation, it is necessary to conduct a detailed market analysis in the locality and consider possible impacts on this key input. Market research conducted by consultancy company Cushman \& Wakefield shows that between second quarters of 2018 and 2019 prime office rents in Prague increased by $1 €$ per square meter. The figure 4 shows the sensitivity of the residual value on the level of the Equivalent Yield.

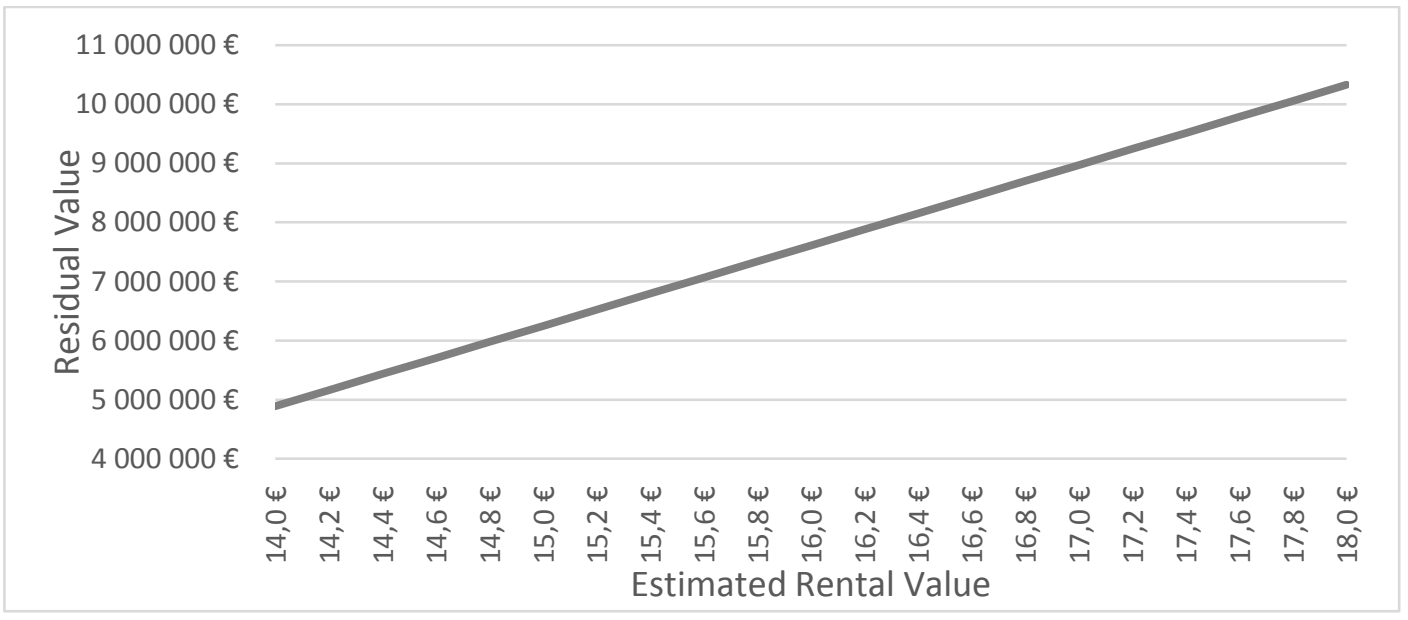

Figure 3: Sensitivity of residual value on ERV (source: Autor)

Construction costs also have a significant impact on Residual value, especially Hard costs. According to the Czech Statistical Office the price of office building constriction between 3Q/2018 and 3Q/2019 has increased by 4,8\% [11]. The period for obtaining a building permit may extend to 5 years or more and the usual period of construction of an office building is 18 months. During that time there may be significant changes in the prices of construction work. Due to this fact the Residual method of valuation is suitable especially for the properties or sites where building permit is obtained.

Development profit is related to the amount of risk associated with achieving the expected return or capital value after the physical completion of the project. It can be assumed that its level will decrease with gradual completion. The level of development profit has a significant impact on the Residual Value. 


\section{Conclusion}

The residual value represents the highest possible price which the most efficient developer would be willing to pay. Residual method involves estimating the cost of a large number of variables and values, which can lead to large differences in valuation, because small differences in inputs spreads to the large difference in the valuation.

Gross Development Value with its key inputs Estimated Rental Value and Equivalent Yield has the greatest impact on the residual value. In times of economic growth, the rents of commercial property usually increase. At the same time, the level of yield is usually compressed. The synergistic effect of these changes is causing a rise in the value of commercial real estate also that the value of development land grows much faster than other real estate asset. The opposite effect occurs in the case of economic depression. For this reason, the input data needs to be sufficiently supported by market research or comparable transaction.

The Residual method is particularly suitable if the building permit is obtained. After building permit obtainment, many other key inputs such as NIA or Construction Costs can be accurately determined. This eliminate possible risks due to sensitivity of residual method.

Finally, it is necessary to add a weakness of sensitivity analysis. It considers the impact of one variable. No understanding is gleaned of how they all interact. In addition, no probabilities are used in sensitivity analysis. For this reason, whilst sensitivity forms a useful start in the risk analysis process, in itself it is not a risk assessment technique.

\section{References}

[1] INTERNATIONAL VALUATION STANDARDS COUNCIL. International valuation standard 2017. EKOPRESS, s.r.o., 2018. ISBN 978-80-87865-44-6.

[2] SAYCE, Sarah et al. Real estate appraisal: from value to worth. 1st ed. Oxford: Blackwell, 2006. 340 S. ISBN 1-4051-0001-X.

[3] WYATT, Peter. Property Valuation in an Economic Context, First edition. Blackwell Publishing Ltd, 2007, ISBN 978-1-4051-3045-5

[4] ENEVER, Nigel., David ISAAC a Mark. DALEY. The valuation of property investments. Seventh edition. London: Routledge, Taylor \& Francis Group, 2010. xii, 220 p. ISBN 978-0-7282-0550-5.

[5] BAUM, Andrew, Nick NUNNINGTON a David MACKMIN. The income approach to property valuation. 5th ed. London: EG Books, 2006. xiii, 334 p. ISBN 0-7282-0464-9.

[6] ROYAL INSTITUTION OF CHARTERED SURVEYORS (RICS); Code of measuring practice, 6th edition, May 2015, ISBN 978-1-84219-332-7

[7] CZECH CONSTRUCTION STANDARDS In: Price indicators in construction 2018 [online], RTS [2018]. [see 11.12.2019]. available at: http://www.stavebnistandardy.cz

[8] CUSHMAN \& WAKEFIELD, Office Market Snapshot - Second Quarter 2018, [online], Cushman \& Wakefield LLP [2018]. [see 16.12.2019]. available at: http://www.cushmanwakefield.cz/cs-cz/researchand-insight/czech-republic

[9] CUSHMAN \& WAKEFIELD, Office Market Snapshot - Second Quarter 2019, [online], Cushman \& Wakefield LLP [2018]. [see 16.12.2019]. available at: http://www.cushmanwakefield.cz/cs-cz/researchand-insight/czech-republic

[10] THE EUROPEAN GROUP OF VALUERS ASSOCIATIONS, European valuation standards 2016, eighth edition. TEGoVA 2016. ISBN 978-90-819060-1-2

[11] CZECH STATISTICAL OFFICE; Price indices of constructions according to CC only four-digit divisions, [online], [see 16.12.2019]. available at: https://www.czso.cz/csu/czso/ipc_cr\#csp 